\title{
Contributions of pollutants from North China Plain to surface ozone at the Shangdianzi GAW Station
}

\author{
W. Lin ${ }^{1}, X . X^{1}, X$. Zhang $^{2}$, and J. Tang ${ }^{1}$ \\ ${ }^{1}$ Key Laboratory for Atmospheric Chemistry, Centre for Atmosphere Watch and Services, Chinese Academy of \\ Meteorological Sciences, China Meteorological Administration, Beijing, China \\ ${ }^{2}$ Institute of Urban Meteorology, China Meteorological Administration, Beijing, China
}

Received: 29 February 2008 - Published in Atmos. Chem. Phys. Discuss.: 21 May 2008

Revised: 1 August 2008 - Accepted: 31 August 2008 - Published: 14 October 2008

\begin{abstract}
Regional ozone pollution has become one of the top environmental concerns in China, especially in those economically vibrant and densely populated regions, such as North China region including Beijing. To address this issue, surface ozone and ancillary data over the period 2004-2006 from the Shangdianzi Regional Background Station in north China were analyzed. Due to the suitable location and valley topography of the site, transport of pollutants from the North China Plain was easily observed and quantified according to surface wind directions. Regional (polluted) and background (clean) ozone concentrations were obtained by detailed statistic analysis. Contribution of pollutants from North China Plain to surface ozone at SDZ was estimated by comparing ozone concentrations observed under SW wind conditions and that under NE wind conditions. The average daily accumulated ozone contribution was estimated to be $240 \mathrm{ppb} \cdot \mathrm{hr}$. The average regional contributions to surface ozone at SDZ from the North China Plain were $21.8 \mathrm{ppb}$ for the whole year, and 19.2, 28.9, 25.0, and 10.0 ppb for spring, summer, autumn, and winter, respectively. The strong ozone contribution in summer led to disappearance of the spring ozone maximum phenomenon at SDZ under winds other than from the NNW to E sectors. The emissions of nitrogen oxide in the North China plain cause a decrease in ozone concentrations in winter.
\end{abstract}

\section{Introduction}

Being one of the greenhouse gases and a key oxidant, ozone plays important role in atmospheric energy budget and chemistry. Changes in atmospheric ozone may contribute to climate change and high levels of surface ozone can cause ad-

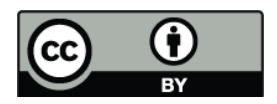

Correspondence to: W. Lin

(linwl@cams.cma.gov.cn) verse effect on the health of human being and ecosystem. Anthropogenic emissions have led to significant changes in atmospheric ozone. These changes, including the increase in tropospheric ozone (Staehelin et al., 1994; Guicherit and Roemer, 2000; Vingarzan, 2004) and the depletion of stratospheric ozone (UNEP, 1989, 1994, 1998) have been important factors for climate change (Forster et al., 2007). In the troposphere, photolysis of ozone by solar UV radiation to electronically excited $\mathrm{O}\left({ }^{1} \mathrm{D}\right)$ and the subsequent reaction with water vapor is the major source of $\mathrm{OH}$ radical. $\mathrm{OH}$ is one of the key species for the chemical reactions in the atmosphere and its abundance is an important index of oxidizing capacity of the atmosphere (Kley et al., 1999; Thompson, 1992; Jacob, 2003). At high $\mathrm{pH}$ value $(\mathrm{pH}>5)$, ozone in aqueous phase reacts rapidly with S(IV) to form sulfate and hence contributes to acid deposition (Tanner and Schorran, 1995).

Ozone originates from in-situ photochemical production in the reactions of its precursors $\left(\mathrm{NO}_{\mathrm{x}}, \mathrm{CO}, \mathrm{VOCs}\right)$ and from vertical and horizontal transport. On the scale of 100 years, the increasing trends of tropospheric ozone are qualitatively in agreement with emission trends of precursors and the increase in tropospheric ozone level has become one of the most crucial environmental problems to solve in the coming decades (Finlayson-Pitts and Pitts, 1997; Guicherit and Roemer, 2000). Ozone at ground level is usually much more influenced by emissions. Because natural and anthropogenic ozone precursor emissions vary strongly from region to region (Staehelin et al., 2001), photochemical sources of ozone have high regional variability. In many mega cities and polluted areas (e.g., city clusters in China and other countries), serious ozone pollution caused by large precursor emissions has concerned civilians and decision-makers (Molina and Molina, 2004; Shao et al., 2006).

China has experienced unprecedented economic growth over the past two decades, accompanied by the development of large-scale industries and services. However, the

Published by Copernicus Publications on behalf of the European Geosciences Union. 


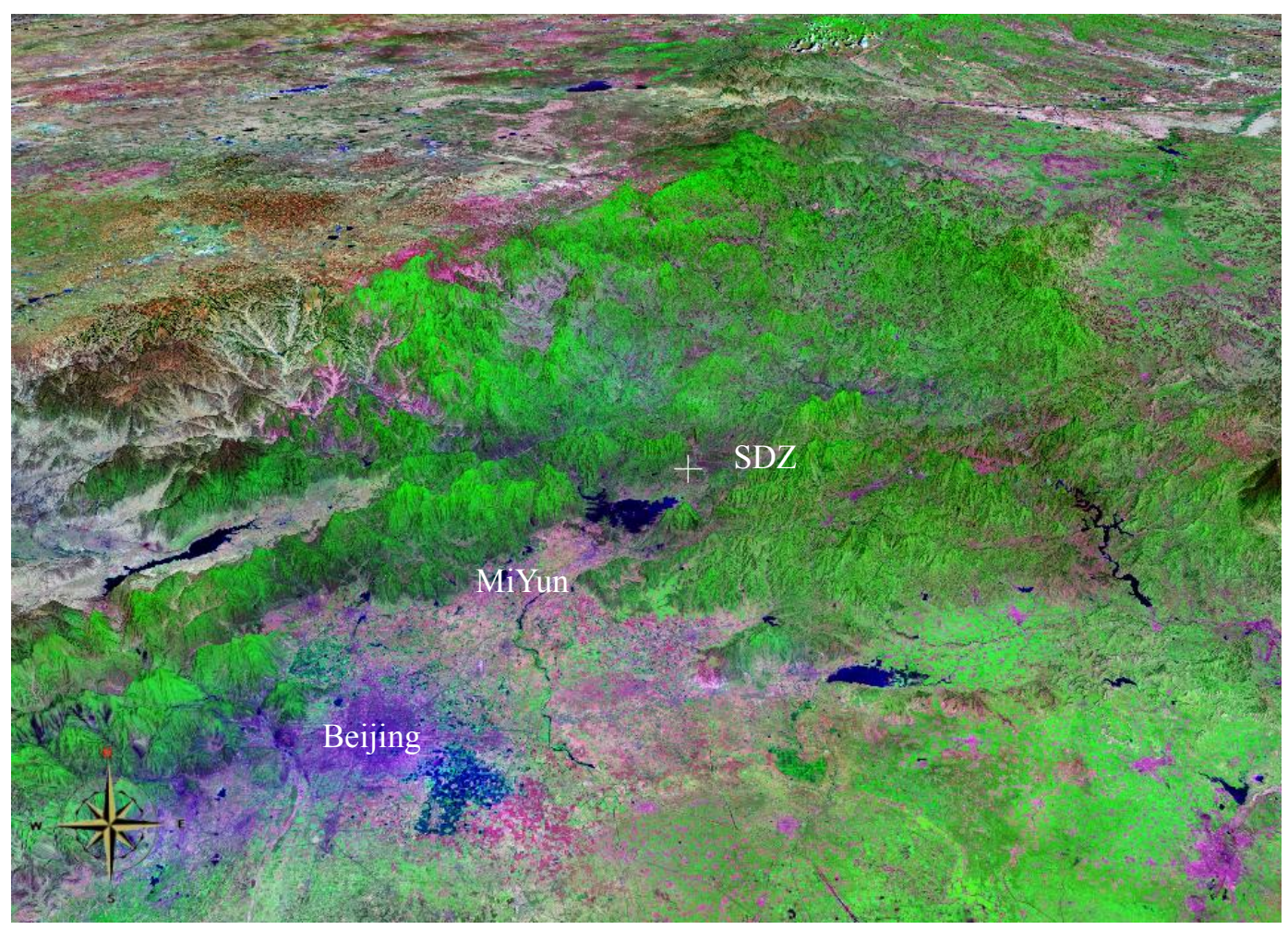

Fig. 1. Map showing the location of the SDZ station (white cross), topography and land use in the surrounding area. NLT landsat7 pseudo color map is from http://worldwind.arc.nasa.gov. Vertical exaggeration is by a factor of 10 .

economic boom has led to a general decline in environmental quality, especially in urban city and in city cluster regions (Zhang et al., 1998; Hao and Wang, 2005; Shao et al., 2006). More and more concerns have been focused on the regional pollutions in those leading economic regions, for example, the Yangtze River delta (Wang et al., 2005), the Pearl River delta (Wang et al., 2003), and the Beijing-Tianjin-Bohai Bay (Xu et al., 2005; Ding et al., 2008). In China, most measurements of surface ozone have been done in urban areas. Since a few years, instruments for surface ozone and other pollutants have been set up at China's background stations to monitor the long-term changes in these pollutants over a regional scale. Some data obtained have been used to study the longterm trends of surface ozone at a regional background station in eastern China (Xu et al., 2008). Ozone and related gases have been measured continuously since 2004 at Shangdianzi (SDZ) regional background station. In this paper, we present analysis of surface ozone data from this station and focus on the contributions of pollutants from North China Plain to background level of surface ozone at the site. A more general analysis of the reactive gases data from the station is given in another paper (Meng et al., 2008).

\section{Site and observations}

Shangdianzi (SDZ; $40^{\circ} 39^{\prime} \mathrm{N}, 117^{\circ} 07^{\prime} \mathrm{E}, 293.9 \mathrm{~m}$ a.s.l.) station is one of the regional Global Atmosphere Watch (GAW) stations in China. The station is located in the northern part of North China Plain and in the Miyun County of Beijing. It is about $100 \mathrm{~km}$ and $55 \mathrm{~km}$ northeasterly to the urban area and Miyun Township of Beijing, respectively (see Fig. 1). Within $30 \mathrm{~km}$ of the site, there are only small villages in mountainous areas with sparse population and thus insignificant anthropogenic emission sources. The instrument building of the station is situated on the south slope of a hill, on the north hill side of a valley with a northeast-southwest orientation. The southwest mouth of the valley is open to Beijing and the south plain. Due to the valley topography, the prevailing winds are northeasterly and southwesterly along the valley trends as shown in Fig. 2 and Fig. 1. On average, the winds have strong diurnal variation with SW in the afternoon and NE from midnight to the morning. Similar wind patterns (figures not shown here) are observed also in many other places to the south of SDZ in the North China plain, e.g. Miyun County $\left(40.38^{\circ} \mathrm{N}, 116.87^{\circ} \mathrm{E}, 71.8 \mathrm{~m}\right.$ a.s.l.), Beijing $\operatorname{City}\left(39.8^{\circ} \mathrm{N}, 116.47^{\circ} \mathrm{E}, 31.3 \mathrm{~m}\right)$, Gucheng site $\left(39^{\circ} 08^{\prime} \mathrm{N}\right.$. $115^{\circ} 40^{\prime} \mathrm{E}, 15.2 \mathrm{~m}$ a.s.1.), Baoding City $\left(38.85^{\circ} \mathrm{N}, 115.52^{\circ} \mathrm{E}\right.$, $17.2 \mathrm{~m}$ ), and Bazhou $\left(39.12^{\circ} \mathrm{N}, 116.38^{\circ} \mathrm{E}, 9 \mathrm{~m}\right.$ a.s.1.), indicating that the wind direction distribution at SDZ is rather 
typical of the larger-scale situation in the North China plain. Therefore, polluted air masses from urban areas and satellite towns of Beijing, and even those regions in south of Beijing at North China Plain, can be easily transported to SDZ under southwesterly winds, while relatively clean air masses are transported to the site with winds from other directions.

A set of commercial instruments from Thermo Environmental Instruments, Inc., USA has been used to measure $\mathrm{O}_{3}$ (TE 49C), $\mathrm{NO} / \mathrm{NO}_{2} / \mathrm{NO}_{\mathrm{x}}$ (TE 42CTL), $\mathrm{CO}$ (TE 48C), and $\mathrm{SO}_{2}$ (TE 43CTL) since January, 2004. Daily zero/span checks are automatically done using a dynamic gas calibrator (TE 146C) in combination with a zero air supply (TE 111) and a set of standard reference gas mixtures (Chemical Metrology \& Analytical Science Division, National Institute of Metrology, Beijing, China). All instruments are housed in an air-conditioned room. Measurement signals are acquired every $6 \mathrm{~s}$ and recorded as 5-min averages. Multipoint calibrations are made every 3-6 months. For ozone, the standards are traceable to the Standard Reference Photometer (SRP) maintained by WMO World Calibration Centre in Switzerland (EMPA). The national standard gases of $\mathrm{SO}_{2}$, NO, and $\mathrm{CO}$ are compared against NIST-traceable standards from Scott Specialty Gases, USA. After the correction of data on the basis of multipoint calibration, hourly average data are calculated and are used for further analysis in this paper. It should be mentioned that the measuring principle used for measurements of $\mathrm{NO}_{2}\left(\mathrm{NO}_{2}\right.$ is converted to $\mathrm{NO}$ by a molybdenum $\mathrm{NO}_{2}$-to-NO converter heated to about 325 $\left.{ }^{\circ}\right)$ at the site suffers from interference of other $\mathrm{NO}_{\mathrm{y}}$ compounds such as PAN and $\mathrm{HNO}_{3}$ (Steinbacher et al., 2007). This implies that the measured $\mathrm{NO}_{2}$ concentrations have to be viewed as an upper limit, particularly in aged air masses such as in summer. Meteorological data, including wind, temperature, relative humidity, and etc., are also obtained from the site, with a resolution of $1 \mathrm{~h}$.

\section{Results and discussion}

\subsection{Diurnal and seasonal variations}

Figure 3 shows the average diurnal variations in each month and monthly variations of surface $\mathrm{O}_{3}$ and $\mathrm{O}_{\mathrm{x}}\left(\mathrm{O}_{3}+\mathrm{NO}_{2}\right)$ concentrations at SDZ. Some detailed statistics of $\mathrm{O}_{3}$ and $\mathrm{O}_{\mathrm{x}}$, including the monthly-averaged diurnal maxima/minima with their appearing time, diurnal amplitudes, and the monthly mean concentrations in each month are listed in Table 1. As can be seen in Fig. 3, both $\mathrm{O}_{3}$ and $\mathrm{O}_{x}$ concentrations show typical diurnal cycles related to photochemistry, with maxima in the afternoon and minima in the early morning. The ozone maxima were in late afternoon (15:0018:00) and the minima were in the morning (05:00-07:00). The higher the ozone maxima, the later they appear. The diurnal variations of both quantities in winter are much less

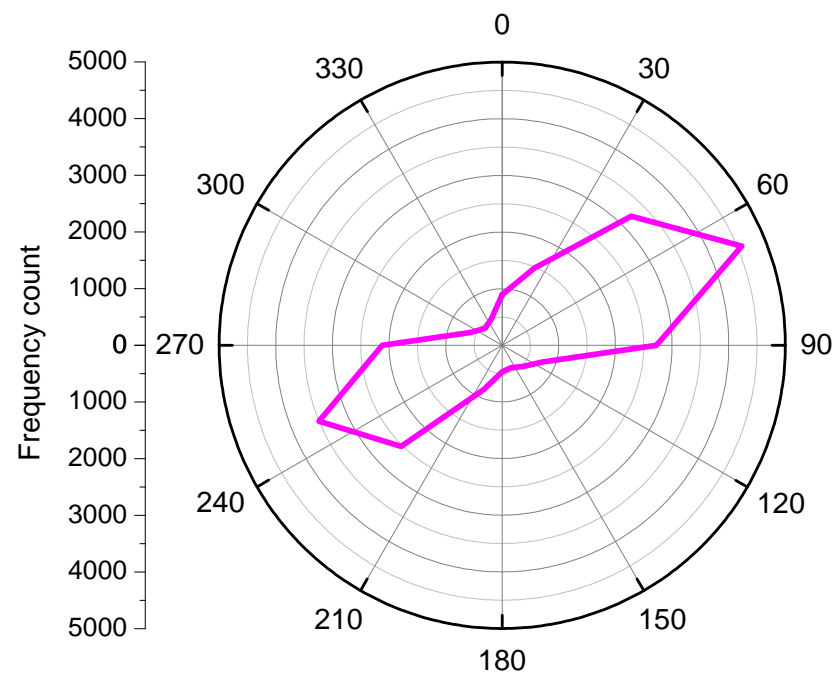

Fig. 2. Wind direction rose of SDZ (from year 2000 to 2006).

significant than those in other seasons. The highest diurnal amplitude of ozone appears in June.

The diurnal amplitudes of surface ozone at SDZ are much more pronounced than those at the Waliguan $\left(36.30^{\circ} \mathrm{N}\right.$, $100.90^{\circ} \mathrm{E}, 3810 \mathrm{~m}$ a.s.1.) Global Baseline Station, a Chinese GAW station at a remote mountain site, where the ozone level is closer to natural background, with small diurnal variations (Ma et al., 2002a; Wang et al., 2006). The diurnal pattern and variability of surface ozone depend very much on the intensity of UV radiation, level and variations of ozone precursors, and vertical and horizontal transport of ozone. In situ photochemical production does not significantly contribute to the diurnal variation of surface ozone at Waliguan because of the extremely low levels of ozone precursors, while at Linan and Longfengshan, the regional GAW stations in eastern and northeastern China, photochemistry plays a key role in diurnal variation of surface ozone (Ma et al., 2002b; Wang et al., 2001). Since SDZ is relatively close to large cities like Beijing and hence larger emission sources of ozone precursors, photochemistry at this site should be much more intensive than at Waliguan. This can explain the difference in the diurnal variability of surface ozone between the two stations.

The curve of meanly mean ozone of SDZ shows two peaks, with the primary and secondary peaks in June and September, respectively. Observation at Mt. Tai $\left(36.25^{\circ} \mathrm{N}\right.$, $117.10^{\circ} \mathrm{E}, 1533 \mathrm{~m}$ a.s.l.) in the North China Plain found a similar seasonal cycle of surface ozone (Li et al., 2007). Seasonal cycles of surface ozone with double peaks were also observed at Lin'an (Wang et al., 2001; Xu et al., 2008) and Mt. Huang (Li et al., 2007) in central-east China. However, the primary peak at these sites appeared a month earlier and the secondary peak a month later at SDZ and Mt. Tai, i.e., the valley between the two peaks is broader at sites in central-east China. This can be explained by stronger impact 
Table 1. The average diurnal maxima/minima with their appeared time, the diurnal ranges, and monthly means of ozone at SDZ.

\begin{tabular}{|c|c|c|c|c|c|c|c|c|}
\hline \multirow[t]{2}{*}{ Month } & \multicolumn{4}{|c|}{$\mathrm{O}_{3}(\mathrm{ppb})$} & \multicolumn{4}{|c|}{$\mathrm{O}_{\mathrm{x}}(\mathrm{ppb})$} \\
\hline & Mean & $\begin{array}{l}\text { Diurnal Max } \\
\text { (appearing time) }\end{array}$ & $\begin{array}{l}\text { Diurnal Min } \\
\text { (appearing time) }\end{array}$ & $\begin{array}{l}\text { Diurnal } \\
\text { amplitude }\end{array}$ & Mean & $\begin{array}{l}\text { Diurnal Max } \\
\text { (appearing time) }\end{array}$ & $\begin{array}{l}\text { Diurnal Min } \\
\text { (appearing time) }\end{array}$ & $\begin{array}{l}\text { Diurnal } \\
\text { amplitude }\end{array}$ \\
\hline Jan & 20.3 & $29.4(16: 00)$ & $14.6(07: 00)$ & 14.8 & 35.9 & $40.9(17: 00)$ & $30.0(09: 00)$ & 10.9 \\
\hline Feb & 27.0 & $35.7(15: 00)$ & $20.5(02: 00)$ & 15.2 & 37.6 & $44.5(17: 00)$ & $31.3(08: 00)$ & 13.1 \\
\hline Mar & 35.0 & $45.8(17: 00)$ & $23.3(07: 00)$ & 22.5 & 44.1 & $53.6(17: 00)$ & $34.7(07: 00)$ & 18.9 \\
\hline Apr & 40.1 & $54.8(16: 00)$ & $24.3(06: 00)$ & 30.5 & 48.7 & $62.4(16: 00)$ & $35.5(07: 00)$ & 26.8 \\
\hline May & 41.4 & $58.6(18: 00)$ & $23.9(06: 00)$ & 34.7 & 49.1 & $65.5(18: 00)$ & $34.1(06: 00)$ & 31.4 \\
\hline Jun & 46.5 & $69.2(18: 00)$ & $23.7(06: 00)$ & 45.5 & 51.7 & $73.5(18: 00)$ & $31.2(06: 00)$ & 42.3 \\
\hline Jul & 33.6 & $50.3(16: 00)$ & $15.0(06: 00)$ & 35.4 & 39.2 & $54.6(18: 00)$ & $22.1(06: 00)$ & 32.5 \\
\hline Aug & 30.9 & $49.5(17: 00)$ & $13.1(06: 00)$ & 36.4 & 37.7 & $54.5(17: 00)$ & $21.5(06: 00)$ & 33.0 \\
\hline Sep & 34.7 & $57.4(17: 00)$ & $15.7(06: 00)$ & 41.7 & 47.8 & $67.2(17: 00)$ & $31.0(07: 00)$ & 36.2 \\
\hline Oct & 28.3 & $46.6(16: 00)$ & $13.5(06: 00)$ & 33.1 & 46.2 & $61.5(17: 00)$ & $32.4(07: 00)$ & 29.1 \\
\hline Nov & 19.4 & $31.9(15: 00)$ & $11.0(06: 00)$ & 20.9 & 36.5 & $43.4(17: 00)$ & $27.6(08: 00)$ & 15.8 \\
\hline Dec & 17.7 & $24.9(15: 00)$ & $13.5(06: 00)$ & 11.4 & 36.9 & $41.9(17: 00)$ & $30.1(09: 00)$ & 11.8 \\
\hline
\end{tabular}

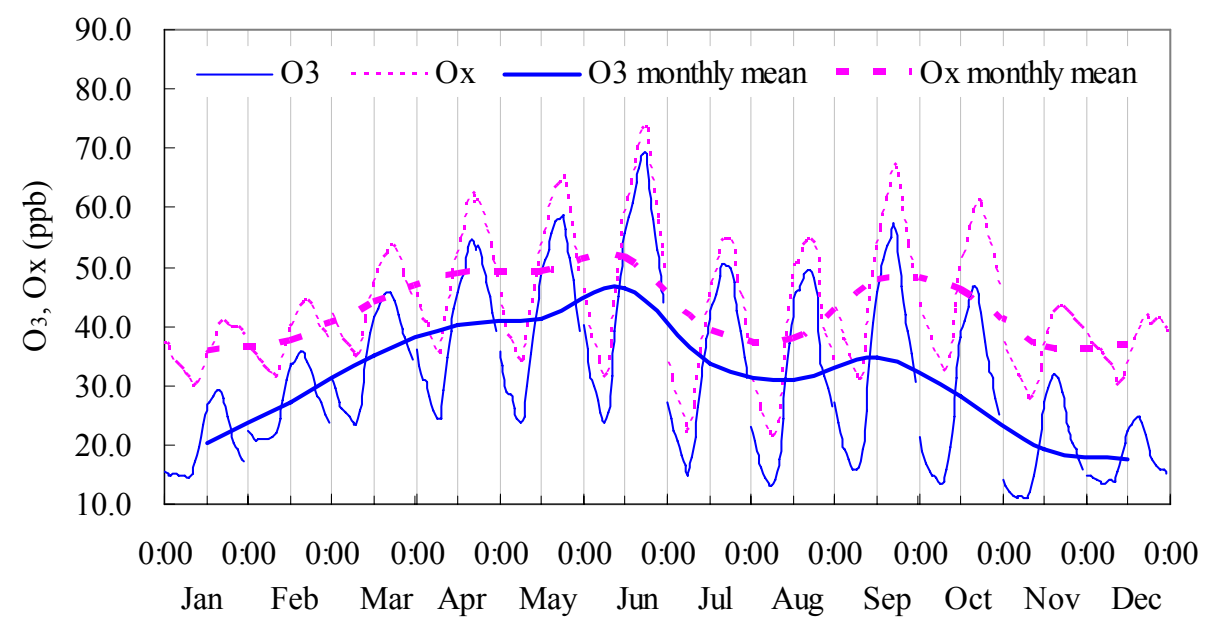

Fig. 3. Average diurnal variations in each month and variations of monthly mean surface $\mathrm{O}_{3}$ and $\mathrm{O}_{\mathrm{x}}$ concentrations at SDZ.

of the Asian summer monsoon on surface ozone at the sites (Wang et al., 2001; Li et al., 2007).

As shown in Table 1, the monthly mean ozone concentration is much lower in the winter months than in the other months. For example, the monthly mean ozone concentration in December is only $17.7 \mathrm{ppb}$ compared to $46.5 \mathrm{ppb}$ in June. Although the monthly mean $\mathrm{O}_{\mathrm{x}}$ concentration is also low in winter months, the summer-winter difference in the $\mathrm{O}_{\mathrm{x}}$ concentration is by far not as large as that in the ozone concentration. In other words, from summer to winter, the total oxidant, as estimated by $\mathrm{O}_{3}+\mathrm{NO}_{2}$, drops less than the ozone concentration. This is because $\mathrm{NO}_{2}$ contributed about $48 \%$ to $\mathrm{O}_{\mathrm{x}}$ in winter (52\% in December) and only $10 \%$ in June.

The year round and summertime average diurnal variations of ozone and the primary pollutant gases are shown in Fig. 4. The ozone concentration increases from its minimum in early morning to its maximum in late afternoon and then decreases till next morning. In recent years, ozone in Beijing city peaks around noon because of photochemical production under the daily strong solar radiation and abundant precursors (Shao et al., 2006). However, as shown in Fig. 4, 


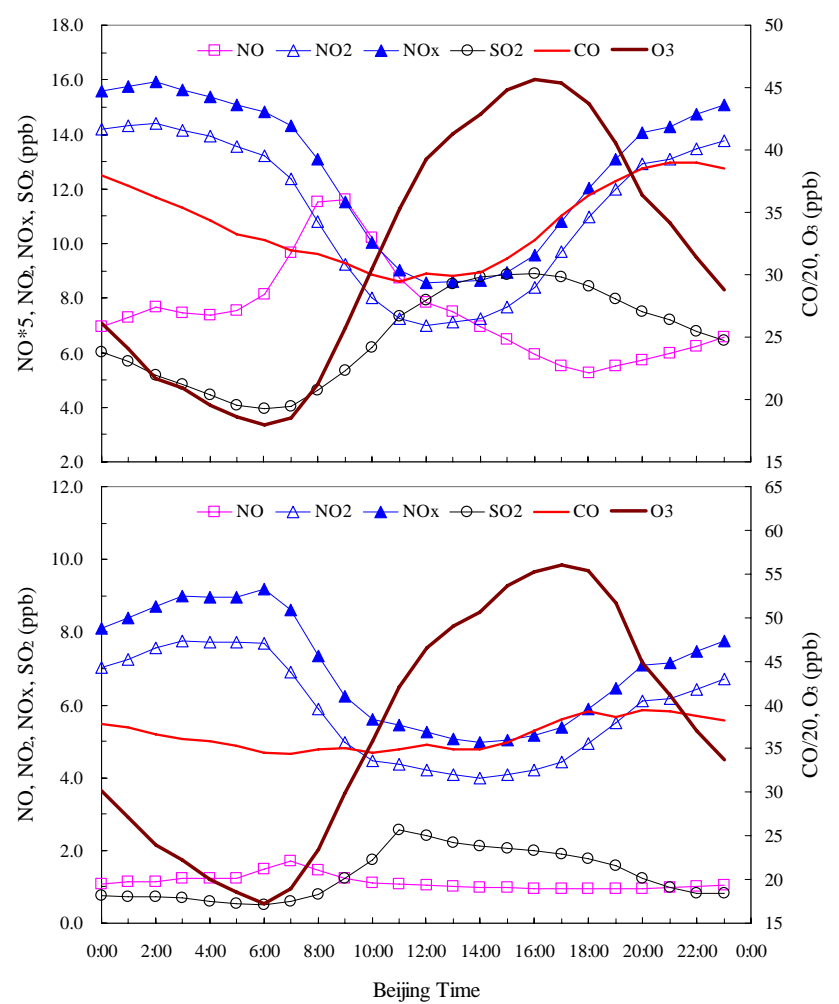

Fig. 4. Average diurnal variations of $\mathrm{O}_{3}, \mathrm{NO} / \mathrm{NO}_{2} / \mathrm{NO}_{\mathrm{x}}, \mathrm{SO}_{2}$, and $\mathrm{CO}$ at SDZ: the whole year (top), summer (bottom).

the ozone concentration in SDZ peaks near dusk and continues its increase in the afternoon, accompanied with the increase of $\mathrm{NO}_{\mathrm{x}}$ and $\mathrm{CO}$ concentrations. $\mathrm{O}_{3}$ and $\mathrm{CO}$ observed at Miyun county in June and July, 2006 by Wang et al. (2008) show similar diurnal variations of $\mathrm{O}_{3}$, but ozone peaking appeared at about 16:00 in June and about 17:00 in July, which was earlier than that in SDZ (about 18:00 in June and July, 2006). These indicate transport of ozone and other pollutants from urban area to SDZ. The strong influence of air quality in rural area by urban plume of Beijing has been also observed by Wang et al. (2006) and Zheng et al. (2005). The diurnal variation of $\mathrm{SO}_{2}$ concentrations shows a distinctly different pattern, with $\mathrm{SO}_{2}$ concentration peaking at 16:00 (average over the year) or 11:00 (in summer) when the PBL is expected to be well mixed. This may indicate the existence of a higher $\mathrm{SO}_{2}$ layer above the nighttime and early morning inversion. Possible sources of this higher $\mathrm{SO}_{2}$ layer may be high chimneys in factories and power plants, the major $\mathrm{SO}_{2}$ emission sources in North China. This explanation can be tested by measurements of $\mathrm{SO}_{2}$ vertical profiles and modeling studies in the future.

\subsection{Ozone frequency distribution}

In the ozone dataset, the total number of hourly average data is 25356 , with the mean $\pm \mathrm{SD}$ of $31.5 \pm 19.9 \mathrm{ppb}$, me-
Table 2. The annual and seasonal statistics of ozone concentrations and the corresponding appearing sectors.

\begin{tabular}{|c|c|c|c|c|c|c|c|}
\hline \multirow{2}{*}{$\begin{array}{l}\text { Period } \\
\text { Year }\end{array}$} & \multicolumn{2}{|c|}{$[\operatorname{Max}]^{*}$} & \multicolumn{2}{|c|}{ [Min]* } & \multirow{2}{*}{$\begin{array}{l}{[\mathrm{CW}]^{*}} \\
20.2\end{array}$} & \multirow{2}{*}{$\begin{array}{l}\text { [Max]-[Min] } \\
21.8\end{array}$} & \multirow{2}{*}{$\begin{array}{l}\mathrm{Max}]-[\mathrm{CW}] \\
23.5\end{array}$} \\
\hline & 43.7 & SW & 21.9 & NEE & & & \\
\hline MAM & 48.4 & SW & 28.2 & NEE & 22.7 & 20.2 & 25.8 \\
\hline JJA & 52.1 & SWW & 23.2 & NEE & 22.9 & 28.9 & 29.2 \\
\hline SON & 43.0 & SWW & 18.0 & NEE & 20.8 & 25.0 & 22.2 \\
\hline DJF & 28.3 & $\mathrm{~N}$ & 18.3 & W & 12.4 & 10.0 & 15.9 \\
\hline
\end{tabular}

*: [Max] means the maximum average value among the $16 \mathrm{sec}-$ tors; [Min] means the minimum average value among the $16 \mathrm{sec}$ tors; $[\mathrm{CW}]$ means the average value under calm wind conditions.

dian of $29.4 \mathrm{ppb}, 25 \%$ percentile of $17.7 \mathrm{ppb}, 75 \%$ percentile of $41.0 \mathrm{ppb}$, maximum of $155.7 \mathrm{ppb}$, and minimum of $0 \mathrm{ppb}$. The mean $\pm \mathrm{SD}$ (median) values of surface ozone for spring, summer, autumn, and winter are $38.8 \pm 17.2$ (38.3) ppb, 36.9 \pm 22.9 (33.5) ppb, $27.5 \pm 20.3$ (24.6) ppb, and $21.7 \pm 11.6$ (23.0) ppb, respectively. Surface ozone frequency distributions (4 ppb per bin) with Lorentz distribution curve fitting for all seasons are shown in Fig. 5. All the distributions can be composed of two Lorentzian curves peaking at different ozone concentrations. Since the concentration of surface ozone at any site and any time depends on the dynamic balance between ozone producing and destroying processes and transport conditions, to some extent, the peak concentration of the ozone frequency distribution, which appears at the highest probability, represents well certain background level of surface ozone. The two Lorentzian curves for each season indicate that SDZ is influenced by two contrast types of airflow, in which ozone is dominated by different processes.

\subsection{Dependence of surface ozone level on wind direction}

Since wind direction gives an insight into the first order advection processes, its correlation with observed ozone data can provide the information about the impact of air-mass transport on the surface ozone variability. In this analysis, the wind direction is divided into 16 standard sectors (clockwise from North) and ozone and $\mathrm{O}_{\mathrm{x}}$ concentrations in the corresponding sectors are averaged. Figure 6 shows the rose distributions of the average $\mathrm{O}_{3}$ and $\mathrm{O}_{x}$ concentrations and $\mathrm{O}_{3}$ concentration under calm wind conditions (wind speed $<$ $0.3 \mathrm{~m} / \mathrm{s}$ ). The rose distributions of ozone and $\mathrm{O}_{\mathrm{x}}$ indicate that average ozone and $\mathrm{O}_{\mathrm{x}}$ concentrations were higher in the SWWSW-W sectors than in other sectors. The lowest ozone and $\mathrm{O}_{\mathrm{x}}$ levels were in the ENE sector. The average ozone concentration in the ENE sector was close to that under calm wind conditions (with a difference of less than $2 \mathrm{ppb}$ ) and $21.8 \mathrm{ppb}$ lower than that in the WSW sector.

Figure 7 shows the average $\mathrm{O}_{3}$ distribution in different wind direction sectors in four seasons. Except in winter, the 

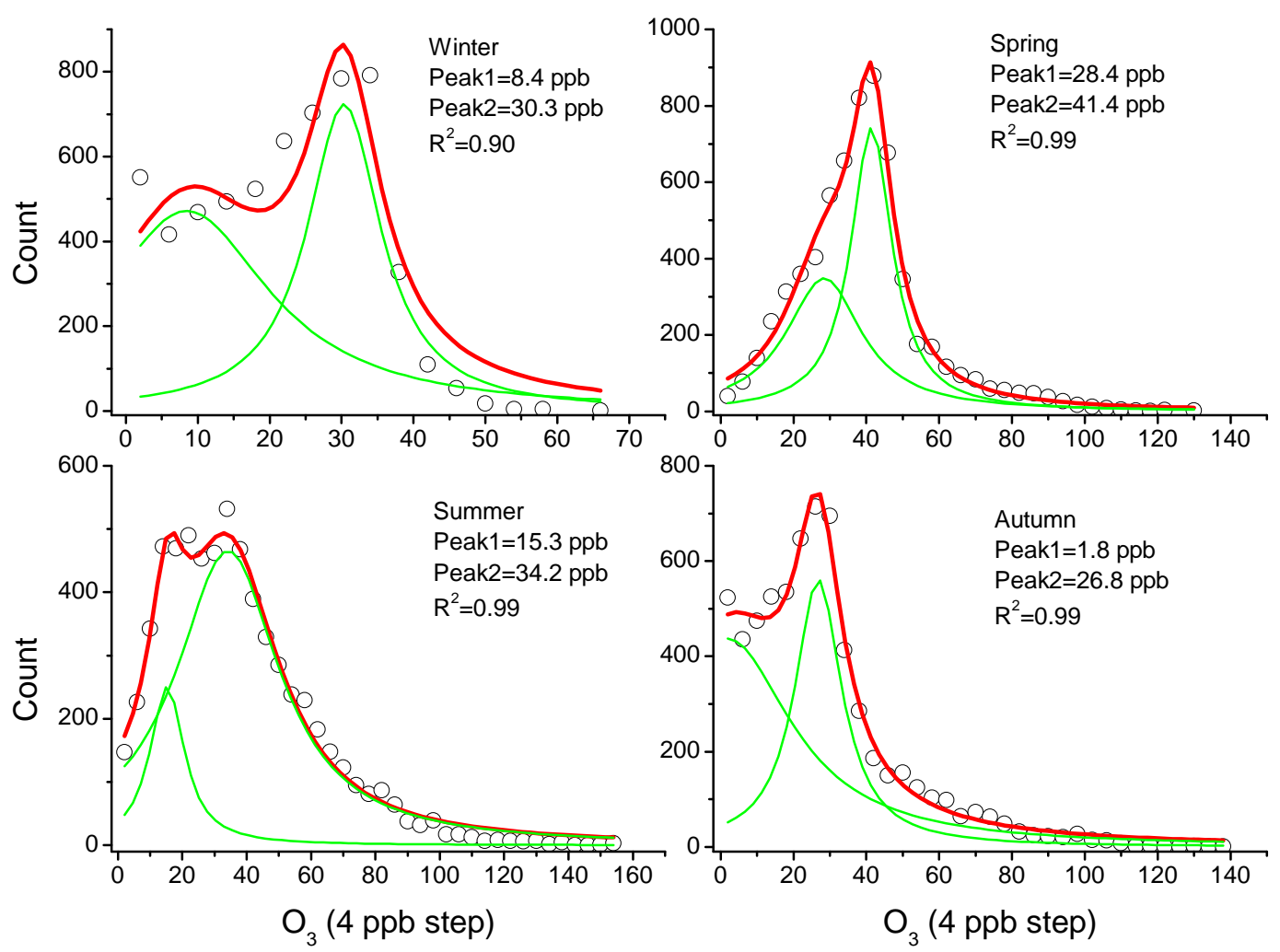

Fig. 5. Surface ozone frequency distribution ( $4 \mathrm{ppb}$ for each bin) with Lorentzian distribution curve fitting at SDZ.

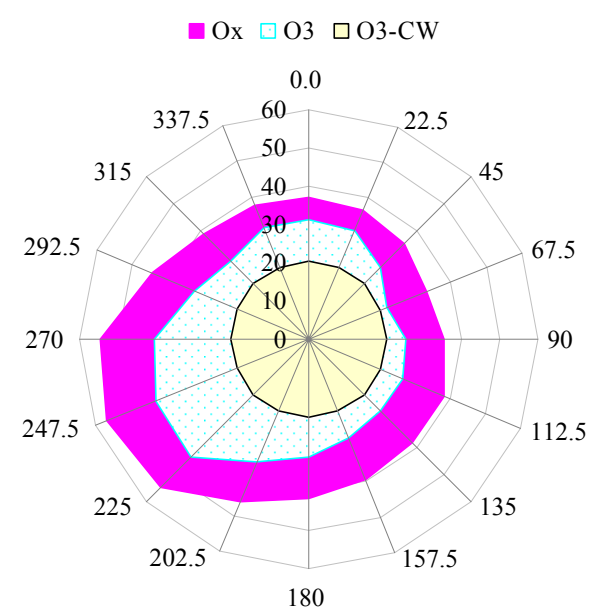

Fig. 6. Average $\mathrm{O}_{3}$ and $\mathrm{O}_{x}$ distributions according to wind directions and average $\mathrm{O}_{3}$ concentration under calm wind conditions $\left(\mathrm{O}_{3}-\mathrm{CW}\right)$. Unit: ppb.

average $\mathrm{O}_{3}$ concentrations in the SW-WSW-W sectors were significantly higher than in other sectors. The lowest concentration was in the ENE sector. The highest $\mathrm{O}_{3}$ concentration in winter appeared in the $\mathrm{N}$ sector. The spring ozone maxi-

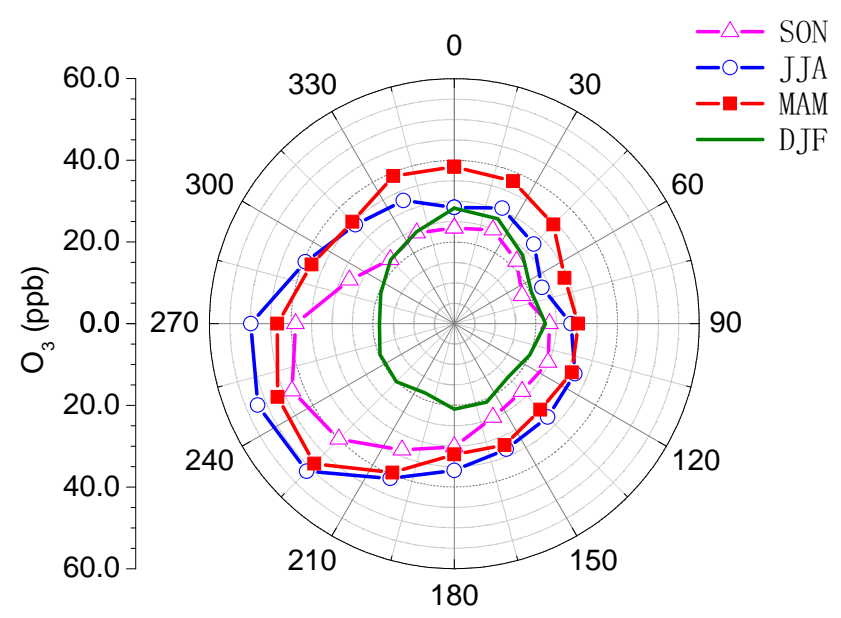

Fig. 7. Seasonal average ozone concentrations in different wind direction sectors.

mum is a northern hemispheric phenomenon (Monks, 2000; Vingarzan, 2004). At SDZ, however, the springtime ozone maximum appeared only in the NNW to E sectors. For the other sectors, highest ozone concentrations appeared in summer and the ozone levels in spring were a little lower than 
those in summer. We believe that air masses transported over the polluted North China Plain had produced more ozone in summer than in any other seasons, leading to the disappearance of the spring ozone maximum in the other sectors. Table 2 summarizes the maximum ([Max] $)$ and minimum ([Min]) values of the annual and seasonal average ozone concentrations and the corresponding appearing sectors. Average ozone concentrations under calm wind conditions ([CW]) and the differences between [Max] and [Min] and between $[\mathrm{Max}]$ and $[\mathrm{CW}]$ are also shown in the table. The ozone difference between [Max] and [Min] was $21.8 \mathrm{ppb}$ for the whole year, and was 19.2, 28.9, 25.0, and $10.0 \mathrm{ppb}$ in spring, summer, autumn, and in winter, respectively.

Figure 8 shows the rose distributions of seasonal average $\mathrm{SO}_{2}, \mathrm{NO}_{\mathrm{x}}, \mathrm{CO}$, temperature, relative humidity $(\mathrm{RH})$, and wind speed. As can be seen in Fig. 8a, 8b, and 8c, in all seasons except summer, the levels of $\mathrm{SO}_{2}, \mathrm{NO}_{\mathrm{x}}$, and $\mathrm{CO}$ concentrations in the $\mathrm{S}-\mathrm{W}$ sectors are much higher than in other sectors, while those in the N-ENE sectors much lower than in other sectors, indicating that polluted air masses are mainly from the S-W sectors (i.e., the North China Plain) and clean air masses are mainly from the N-ENE sectors. The rose distribution of RHshown in Fig. 8d, indicates that except in summer, air masses from the $\mathrm{N}$ sector are significantly drier than from other sectors. Because air masses from the $\mathrm{N}$ sector are characterized as having low humidity, relatively high ozone, and lower $\mathrm{SO}_{2}, \mathrm{NO}_{\mathrm{x}}$, and $\mathrm{CO}$ concentrations, it is likely that they contain more air from the free troposphere than those from other sectors. The rose distributions of temperature and wind speed, as shown in Figs. 8e and 8f, respectively, suggest that air masses from the North China Plain are warmer and are transported to SDZ under higher local wind speed conditions.

Observed ozone concentrations in air from different sectors (clean and polluted) should stand for the levels of different background ozone. To simplify the situation concerned here, we differentiate two kinds of background ozone, clean background ozone and regional background ozone, following the definitions by Kourtidis et al. (1997) and Bronnimann et al. (1998). Clean background ozone means the ozone level in the air from the relatively clean sectors. Regional background ozone is the ozone level over a large area $\left(1000 \times 1000 \mathrm{~km}^{2}\right)$ produced by the mixing of air masses of different origin outside and inside the defined area. The definition of regional background is made under the ideal status of "well mixing". So far, it is difficult to recognize the exact regional background ozone for a certain moment. In view of the fact that SDZ is quite distant from major sources, we assume that air masses from the North China Plain have been well mixed before arriving at SDZ. Under this assumption, the average of the surface ozone concentration in the southwest sector for a given period can be considered as the typical value of the regional (polluted) background ozone of the North China Plain for this period. Ozone in air masses from the clean sectors, i.e., the N-ENE sectors can be treated as the clean background ozone for SDZ. Therefore, the contribution of pollutants from the North China Plain to the ozone level at SDZ can be estimated to be the difference between the regional background and the clean background ozone for the site.

Figure 9 shows the year round average diurnal variations of ozone concentrations corresponding to the NE and SW wind direction sectors. The difference between the SW and NE curves is also shown as bars in Fig. 9. Although the two diurnal variation curves look similar in terms of their general patterns, they differ at points. The first and profound difference is that the SW curve shows higher ozone concentrations than the NE curve at all time of the day, particularly in the afternoon. The second difference is the timing of the maximum and minimum ozone concentrations, with the maximum and minimum in the SW curve being 1-2 $\mathrm{h}$ later than those in the NE curve. The SW curve has the typical features of the diurnal ozone variation in aged air masses, e.g., enhanced ozone level and later ozone daily maximum. This supports the idea that ozone concentration at SDZ under the southwesterly wind condition is very strongly influenced by the transport of polluted air masses from the North China Plain and photochemical production during the transport of the air masses. Assuming that the SW and NE curves represent the average diurnal variations of the regional background ozone and the clean background ozone at SDZ, respectively, we can estimate the net contribution of the North China Plain to surface ozone at SDZ using the difference between the SW and NE curves. As shown in Fig. 9, the difference between the two curves is at highest $20 \mathrm{ppb}(17: 00)$ and at lowest $1.6 \mathrm{ppb}$ (07:00). The daily average of the difference is $10 \mathrm{ppb}$, and the sum of the daily average of the difference is up to $240 \mathrm{ppb} \cdot \mathrm{hr}$.

The ozone contribution of the North China Plain depends highly on season. Figure 10 shows the seasonal variations of ozone concentrations corresponding to the SW and NE wind direction sectors and their difference. Similar to diurnal variation in Fig. 9, the seasonal variations of the ozone difference between the SW and NE curves in Fig. 10 can be used to estimate the net contribution of the North China Plain to surface ozone at SDZ for the time scale of month, season, and year. There are two peaks in the seasonal variation of the ozone difference, with the primary one (about $34 \mathrm{ppb}$ ) being in September and the secondary one (about $29 \mathrm{ppb}$ ) being in June. In winter, the ozone difference is negative, suggesting that air masses from the North China Plain contain less ozone than those from the NE sector. This does not mean that the winter air in the North China Plain is cleaner than the clean background at all. Rather it is caused by the pollution in the North China Plain. Photochemical ozone production in the planetary boundary layer is very small in winter and therefore higher $\mathrm{NO}_{\mathrm{x}}$ concentration in the $\mathrm{SW}$ sector (see Fig. 8c) leads to chemical ozone destruction (gas titration, i.e., reaction of $\mathrm{NO}$ with $\mathrm{O}_{3}$ ), explaining lower ozone concentration in the polluted sector than in the clean background air (see Fig. 10). To prove this, the seasonal variations of $\mathrm{O}_{\mathrm{x}}$ 


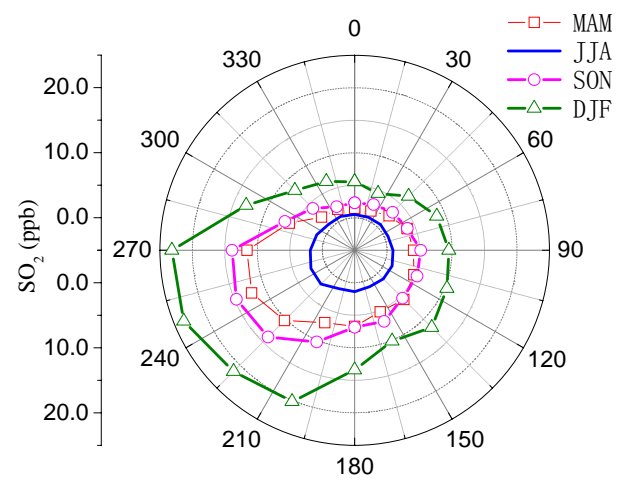

(a)
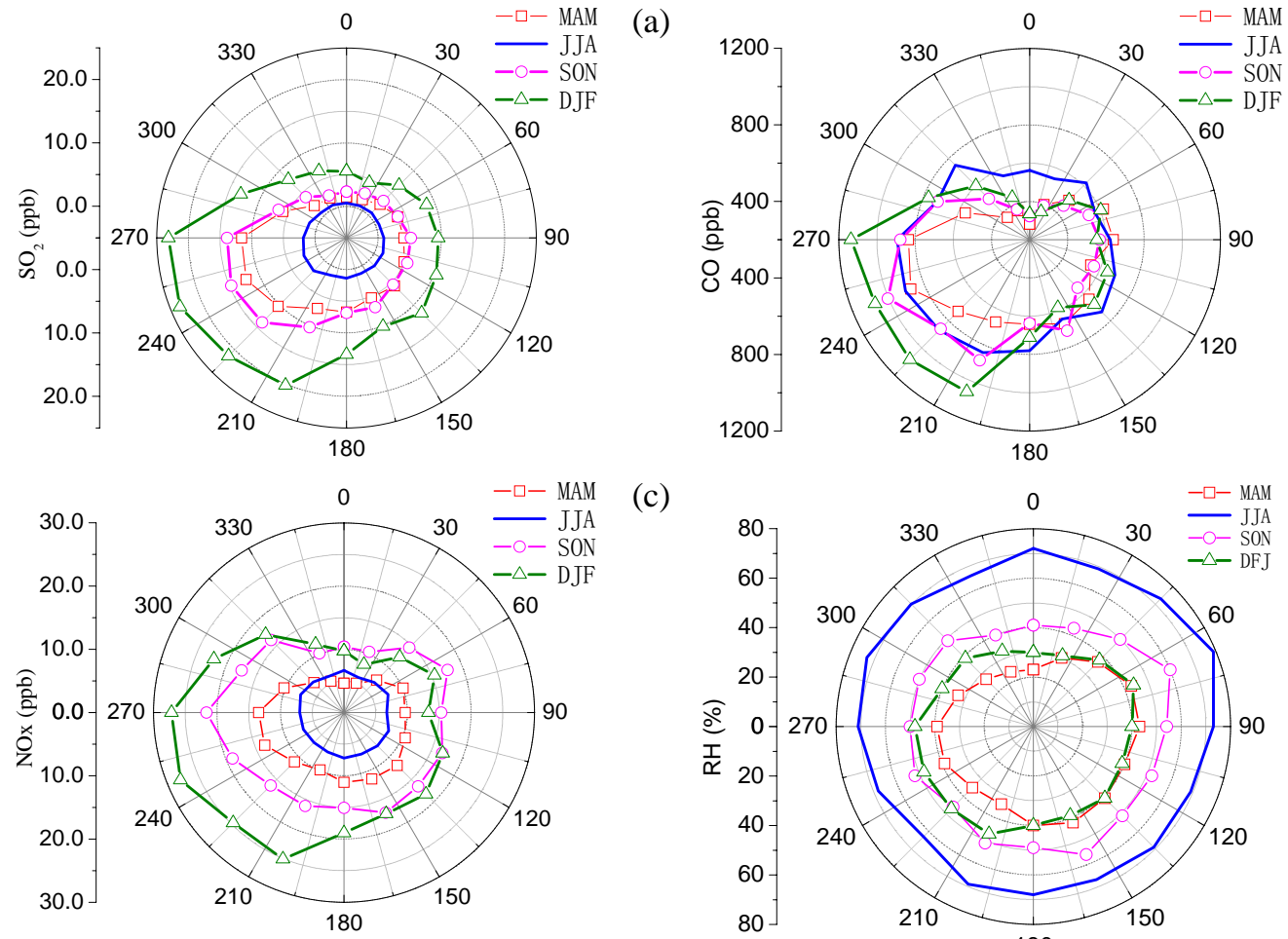

(c)

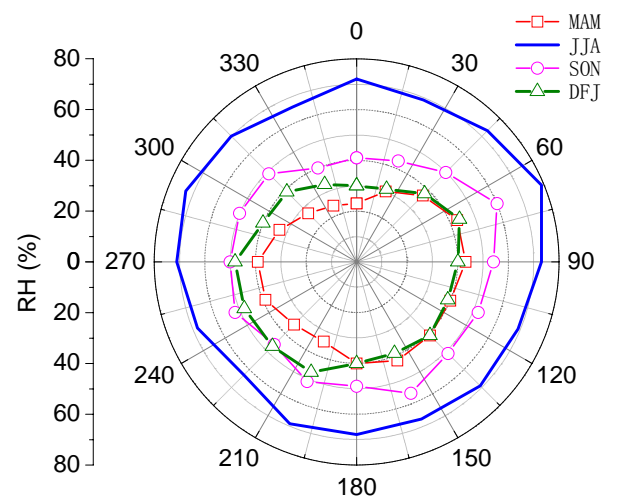

(d)

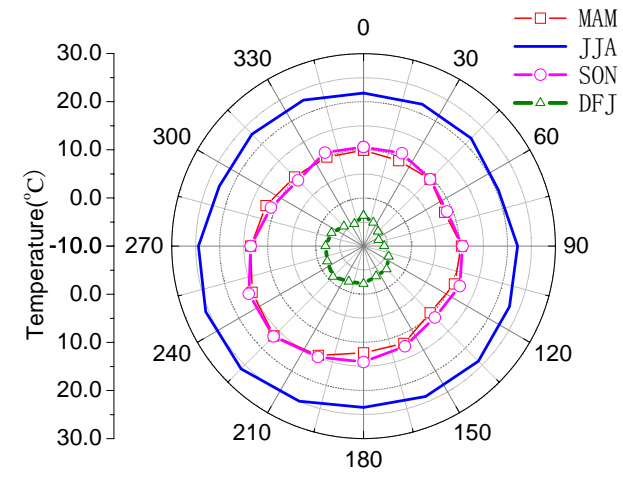

(e)

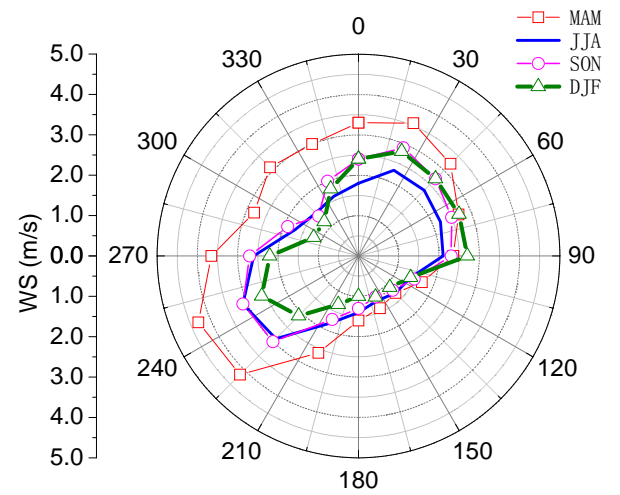

Fig. 8. Dependence of seasonal average $\mathrm{SO}_{2}, \mathrm{NO}_{\mathrm{x}}, \mathrm{CO}$, temperature, relative humidity (RH), and wind speed (WS) on wind direction.

corresponding to the SW and NE wind direction sectors and their difference are plotted in Fig. 11. Obviously, the $\mathrm{O}_{\mathrm{x}}$ difference is positive in all seasons, suggesting that even in the cold season the total oxidant is not reduced by the pollutants from the North China Plain, but enhanced.

In this section, we have classified the ozone data at SDZ into clean and polluted backgrounds using surface winds and further quantified the regional contribution from the North China Plain. The method applied may cause larger uncertainties in the results because the surface winds at SDZ may be strongly influenced by the local topography. However, careful analysis using both wind data from the sites in the North China Plain and NCEP/NCAR reanalysis data suggests that the surface wind observed at SDZ seemed to be more in- fluenced by meso- to large-scale airflows than by the local topography (Lin et al., 2008). The orientation of the valley near SDZ, which is nearly parallel to the prevailing winds in the north of the North China Plain, may have helped to reduce the influences from the local topography. Therefore, it is likely that the uncertainty caused by the local topography is not as large as it seems to be.

\section{Conclusions}

Measurements of surface ozone at SDZ from the period 2004-2006, together with ancillary data, were summarized and used to study the impact of pollutants from the North China Plain on surface ozone at the background site. Surface 


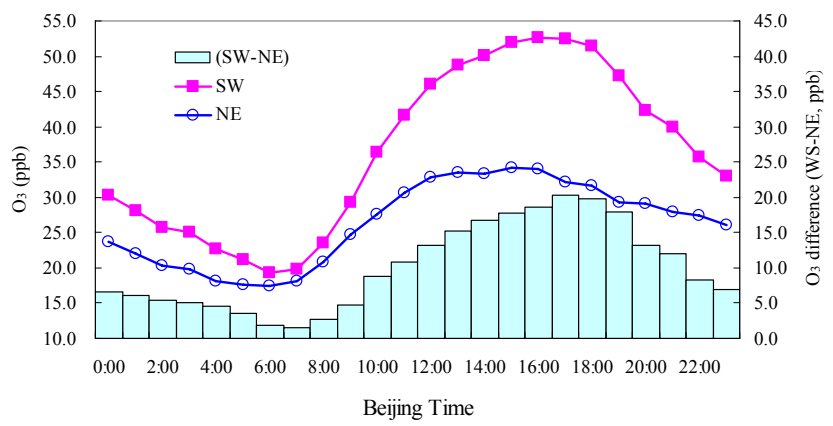

Fig. 9. The annually averaged diurnal variations of ozone concentrations for $\mathrm{N}-\mathrm{E}$ and $\mathrm{S}-\mathrm{W}$ wind direction sectors.

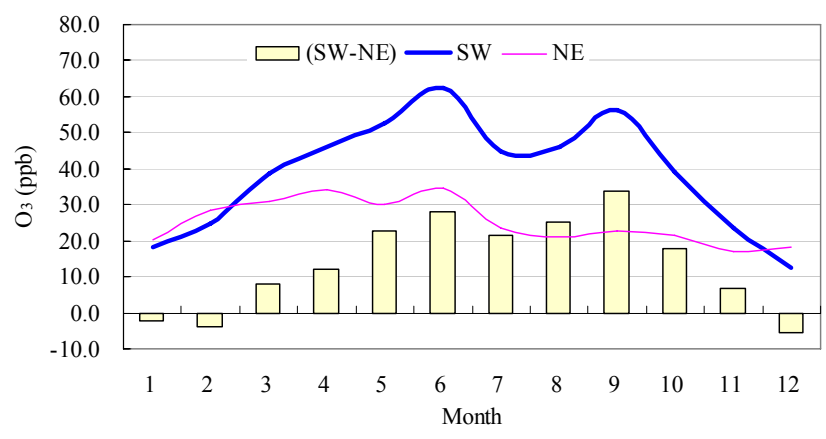

Fig. 10. Seasonal variations of average $\mathrm{O}_{3}$ concentrations corresponding to the $\mathrm{S}-\mathrm{W}$ and $\mathrm{N}-\mathrm{E}$ wind direction sectors and their difference.

ozone concentrations at SDZ show some unique properties because of its location and the surrounding topography. The seasonal variation of surface ozone at SDZ shows a doublepeak pattern, with the primary and secondary peaks being in June and September, respectively. This pattern reflects the effect of Asian summer monsoon on the level of surface ozone at the site. Monthly mean concentrations of surface ozone from January to December were 20.3, 27.0, 35.0, 40.1, 41.4, $46.5,33.6,30.9,34.7,28.3,19.4$, and $17.7 \mathrm{ppb}$, respectively. The average diurnal variation of surface ozone at SDZ takes the form of single wave and shows significant influence of photochemistry. An unusual phenomenon is that ozone peaks near dusk and continues its increase in the afternoon, accompanied with the increase of $\mathrm{NO}_{\mathrm{x}}$ and $\mathrm{CO}$ concentrations. This can be attributed to transport of ozone and other pollutants from urban area to SDZ.

Surface ozone frequency distributions for all season can be composed of two Lorentzian curves peaking at different ozone concentrations, indicating that SDZ is influenced by two different types of airflow, in which ozone is dominated by different processes. Being a station at the north edge of the North China Plain and a site with valley topography, SDZ is an ideal site for capturing the regional (polluted) ozone background of North China Plain and the clean ozone background according to different wind directions. Contribution

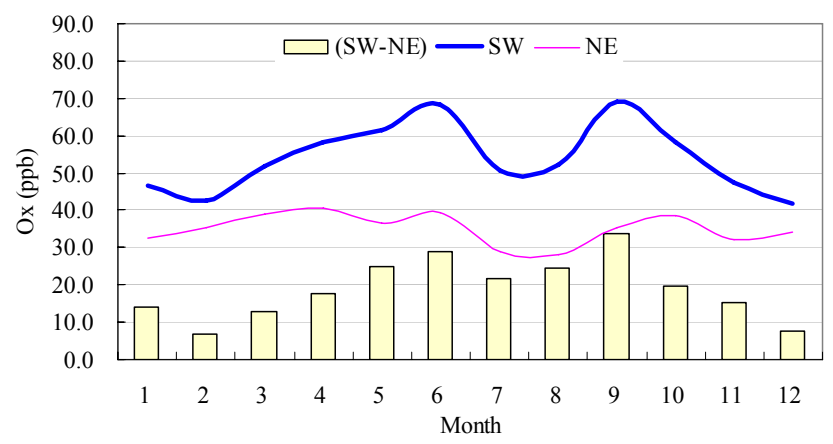

Fig. 11. Seasonal change of average $O_{x}$ concentrations corresponding to the $\mathrm{S}-\mathrm{W}$ and $\mathrm{N}-\mathrm{E}$ wind direction sectors and their difference.

of pollutants from North China Plain to surface ozone at SDZ can be estimated by comparing ozone concentrations observed under SW wind conditions and that under NE wind conditions. On the average, the daily accumulated ozone contribution amounts to $240 \mathrm{ppb} \cdot \mathrm{hr}$. The average regional contributions to surface ozone at SDZ from the North China Plain are estimated to be $21.8 \mathrm{ppb}$ for the whole year, and 19.2, 28.9, 25.0, and $10.0 \mathrm{ppb}$ for spring, summer, autumn, and winter, respectively. From May to September, the estimated ozone contributions are all above $20 \mathrm{ppb}$ with the most significant contribution (34 ppb) being in September. Caused by the strong ozone contribution in summer, the spring ozone maximum phenomenon disappears at SDZ under winds other than from the WNN to E sectors. The emissions of nitrogen oxide in the North China plain cause a decrease in ozone concentrations in winter.

Acknowledgements. We thank the staff of the Shangdianzi station for carrying out the measurements. This work is supported by the "National Basic Research Program of China" (No. 2005CB4222002) and by Chinese Natural Science Foundation (Grants 20407001 and 40775074) and by the CMA project (CCSF2007-15). X. Xu thanks the grant from the Ministry of Personnel of the Peoples Republic of China.

Edited by: A. Stohl

\section{References}

Bronnimann, S., Schuepbach, E., Zanis, P., Buchmann, B., and Wanner, H.: A climatology of regional background ozone at different elevations in Switzerland (1992-1998), Atmos. Environ., 34, 5191-5198, 2000.

Ding, A. J., Wang, T., Thouret, V., Cammas, J.-P., and Nédélec, P.: Tropospheric ozone climatology over Beijing: analysis of aircraft data from the MOZAIC program, Atmos. Chem. Phys., 8, 1-13, 2008, http://www.atmos-chem-phys.net/8/1/2008/.

Finlayson-Pitts, B. J. and Pitts, J. J. N.: Tropospheric air pollution: ozone, airborne toxics, polycyclic aromatic hydrocarbons, and particles (J), Science, 276, 1045-1051, 1997. 
Forster, P., Ramaswamy, V., Artaxo, P., et al.: Changes in Atmospheric Constituents and in Radiative Forcing, in: Climate Change 2007: The Physical Science Basis. Contribution of Working Group I to the Fourth Assessment Report of the Intergovernmental Panel on Climate Change, edited by: Solomon, S., Qin, D., Manning, M., Chen, Z., Marquis, M., Averyt, K. B., Tignor, M., and Miller, H. L., Cambridge University Press, Cambridge, United Kingdom and New York, NY, USA, 2007.

Guicherit, R. and Roemer, M.: Tropospheric ozone trends, Chemosphere: Global Change Science, 2, 167-183, 2000.

Hao, J. M. and Wang, L. T.: Improving urban air quality in China: Beijing case study, J. Air Waste Manage. Assoc., 55, 1298-1305, 2005.

Jacob, D. J.: The Oxidizing Power of the Atmosphere, in: Handbook of Weather, edited by: Potter, T., Colman, B., Fishman, J., et al., Climate and Water, Chichest, John Wiley\& Sons, Inc., 1-18, 2003.

Kley, D., Kleinmann, M., Sanderman, H., and Krupa, S.: Photochemical oxidants: state of the science, Environ. Poll., 100, 1942, 1999.

Kourtidis, K., Ziomas, I., Zerefos, C., Balis, D., Suppan, P., Vasaras, A., Kosmidis, V., and Kentarchos, A.: On the background ozone values in Greece, in: The Oxidizing Capacity of the Troposphere, edited by: Larsen, B., Versino, B., and Angeletti, G., EUR 17482, EU, Brussels, 387-390, 1997.

Li, J., Wang, Z., Akimoto, H., Gao, C., Pochanart, P., and Wang, X.: Modeling study of ozone seasonal cycle in the lower troposphere over East Asia, J. Geophys. Res., 112, D22S25, doi:10.1029/2006JD008209, 2007.

Lin, W., Xu, X., Zhang, X., and Tang, J: Response to Interactive comments on "Contributions of pollutants from North China Plain to surface ozone at the Shangdianzi GAW station" by Lin et al., Atmos. Chem. Phys. Discuss., 8, S1-S12, 2008.

Ma, J., Tang, J., Zhou, X., and Zhang, X.: Estimates of the chemical budget for ozone at Waliguan Observatory, J. Atmos. Chem., 41, 21-48, 2002a.

Ma, J., Zhou, X., and Hauglustaine, D.: Summertime tropospheric ozone over China simulated with a regional chemical transport model: 2. Source contributions and budget, J. Geophys. Res., 107(D22), 4612, doi:10.1029/2001JD001355, 2002b.

Molina, M. J. and Molina, L. T.: Megacities and atmospheric pollution, J. Air Waste Manage. Assoc., 54, 644-680, 2004.

Meng, Z. Y., Xu, X. B., Yan, P., Ding, G. A., Tang, J., Lin, W. L., Xu, X. D., and Wang, S. F.: Characteristics of trace gaseous pollutants at a regional background station in Northern China, Atmos. Chem. Phys. Discuss., 8, 9405-9433, 2008, http://www.atmos-chem-phys-discuss.net/8/9405/2008/.

Monks, P. S.: A review of the observations and origins of the spring ozone maximum, Atmos. Environ., 34, 3545-3561, 2000.

Shao, M., Tang, X., Zhang, Y., and Li, W.: City clusters in China: air and surface water pollution, Front. Ecol. Environ., 4(7), 353$361,2006$.

Staehelin, J., Thudium, J., Bühler, R., Volz-Thomas, A., and Graber W.: Surface ozone trends at Arosa (Switzerland), Atmos. Environ., 28, 75-87, 1994.

Staehelin, J., Harris, N. R. P., Appenzeller, C., and Eberhard, J.: Ozone Trends: a Review, Rev. Geophys., 39(2), 231-290, 2001.

Steinbacher, M., Zellweger, C., Schwarzenbach, B., Bugmann, S., Buchmann, B., Ordonez, C., Prevot, A. S. H., and Hueglin, C.:
Nitrogen oxide measurements at rural sites in Switzerland: Bias of conventional measurement technique, J. Geophys. Res., 112, D11307, doi:10.1029/2006JD00791, 2007.

Tanner, R. L. and Schorran, D. E.: Measurement of gaseous peroxides near the Grand Canyon, implication for summertime visibility impairment from aqueous phase secondary sulfate formation, Atmos. Environ., 29, 1113-1122, 1995.

Thompson, A.: The Oxidizing Capacity of the Earth's Atmosphere: Probable Past and Future Changes, Science, 256, 1157-1165, 1992.

UNEP.: Environmental Effects Panel Report, Nairobi, UNEP, 1989.

UNEP: Environmental Effects of Ozone Depletion: 1994 \& 1998 Assessment, Nairobi: UNEP, 1994\&1998.

Vingarzan, R.: A review of surface ozone background levels and trends, Atmos. Environ., 38, 3431-3442, 2004.

Wang, H., Kiang, C. S., Tang, X., Zhou, X., and Chameides, W.: Surface ozone: A likely threat to crops in Yangtze delta of China, Atmos. Environ., 39, 3843-3850, 2005.

Wang, T., Cheung, T. F., Anson, M., and Li, Y. S.: Ozone and related gaseous pollutants in the boundary layer of eastern China: Overview of the recent measurements at a rural site, Geophys. Res. Lett., 28, 2373-2376, 2001.

Wang, T., Ding, A., Gao, J. and Wu, W.: Strong ozone production in urban plumes from Beijing, China, Geophys. Res. Lett., 33, L21806, doi: 10.1029/2006GL027689, 2006.

Wang, T., Poon, C. N., Kwok, Y. H., and Li, Y. S.: Characterizing the temporal variability and emission patterns of pollution plumes in the Pearl River Delta of China, Atmos. Environ., 37, 3539-3550, 2003.

Wang, T., Wong, H., Tang, J., Ding, A., Wu, W., and Zhang, $\mathrm{X}$.: On the origin of surface ozone and reactive nitrogen observed at a remote mountain site in the northeastern QinghaiTibetan Plateau, western China, J. Geophys. Res., 111, D08303, doi:10.1029/2005JD006527, 2006.

Wang, Y., McElroy, M. B., Munger, J. W., Hao, J., Ma, H., Nielsen, C. P., and Chen, Y.: Variations of $\mathrm{O}_{3}$ and $\mathrm{CO}$ in summertime at a rural site near Beijing, Atmos. Chem. Phys. Discuss., 8, $10397-$ 10414, 2008, http://www.atmos-chem-phys-discuss.net/8/10397/2008/.

Xu, X., Lin, W., Wang, T., Yan, P., Tang, J. Meng, Z., and Wang, Y.: Long-term trend of surface ozone at a regional background station in eastern China 1991-2006: Enhanced variability, Atmos. Chem. Phys., 8, 2595-2067, 2008, http://www.atmos-chem-phys.net/8/2595/2008/.

Xu, X., Xie, L., Ding, G., and Bian, L.: Beijing Air Pollution Project To Benefit 2008 Olympic Games, Am. Meteorol. Soc., 1543-1544, 2005.

Zhang, Y., Shao, K., Tang, X., and Li, J.: The Study of Urban Photochemical Smog Pollution in China, Acta Scientiarum Naturalium Universitatis Pekinensis (Chinese with English abstract), 34(23), 392-400, 1998.

Zheng, X., Ding, G., Yu, H., Liu, Y., and Xu, X.: Vertical distribution of ozone in the planteary boundary layer at the Ming Tombs, Beijing, Science in China (D Earth Sciences), 48 (Supp.), 55-63, 2005. 